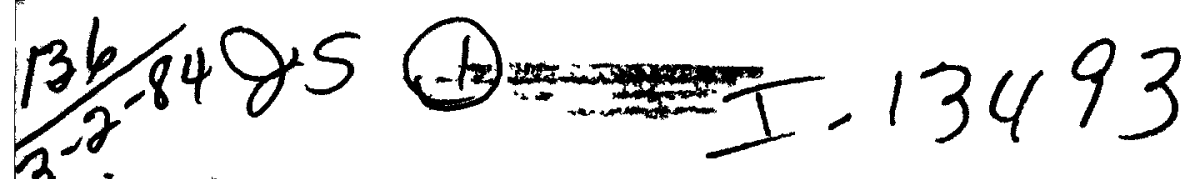

RFP:3589

February 8, 1984

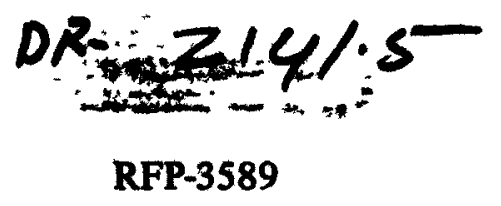

February 8, 1984

\title{
LABORATORY-SCALE EVALUATIONS OF \\ ALTERNATIVE PLUTONIUM PRECIPITATION METHODS
}

Larry L. Martella

Mark T. Saba

Georgianne K. Campbell

\section{DO NOT MICROFILIM

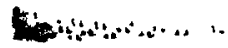 COVER}

Rockwell International
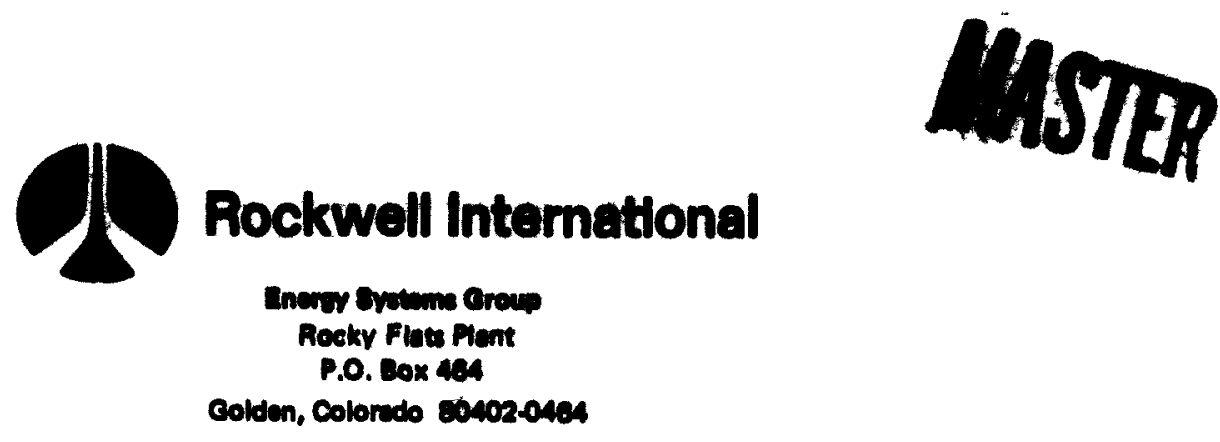

U. 8. DEPAATMENT OF ENEAGY CONTAACT OL-ACO4-70DPOssss 


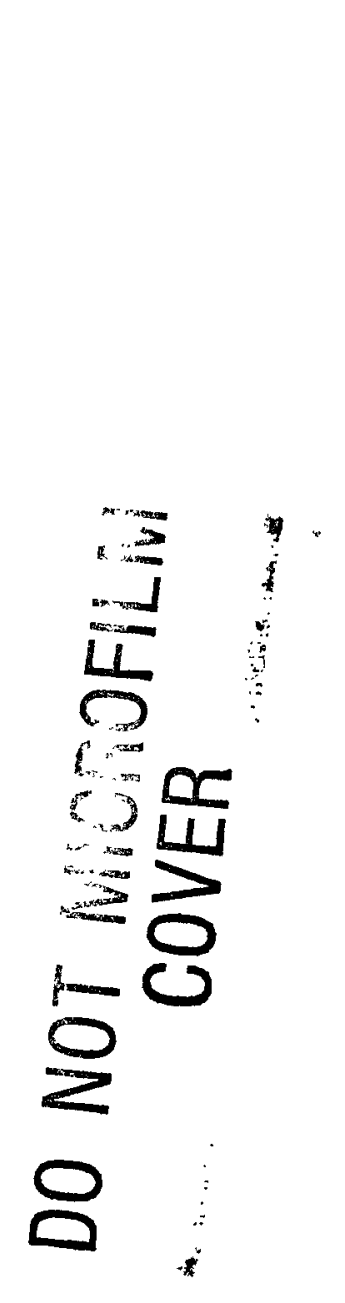

This report was prepared as an account of work sponsored by the United States Government. Neither the United States nor the United States Department of Energy, nor any of their employees, nor any of their contractors, subcontractors, or their employees, make any warranty, expressed or implied, or assumes any legal liability or responsibility for the accuracy, completeness, or usefulness of any information, apparatus, product, or process disclosed, or represents that its use would not infringe privately owned rights.

Printed in the United States of America Available from the

National Technical Information Service

U.S. Department of Commerce

Springfield, Virgina 22161

Page Range

001-025

026-050

051-075

076-100

101-125
Domestic Price*

$\$ 6.00$

7.50

9.00

10.50

12.00

*All microfiche are priced at $\$ 5.00$

Prices Subject to Change Without Notice 
Printed

February 8, 1984
RFP-3589

UC-10 CHEMICAL SEPARATIONS

PROCESSES FOR

PLUTONIUM AND URANIUM

DOE/TIC-4500 (Rev. 72)

\title{
LABORATORY-SCALE EVALUATIONS OF \\ ALTERNATIVE PLUTONIUM PRECIPITATION METHODS
}

\author{
Larry L. Martella \\ Mark T. Saba \\ Georgianne K. Campbell \\ G. A. Riordan, Editor \\ L. M. Morales, Compositor
}

RFP- -3589

DE84 007334

\section{DISCLAIMER}

This report was prepared as an account of work sponsored by an agency of the United States Government. Neither the United States Government nor any agency thereof, nor any of their employees, makes any warranty, express or implied, or assumes any legal liability or responsibility for the accuracy, completeness, or usefulness of any information, apparatus, product, or process disclosed, or represents that its use would not infringe privately owned rights. Reference herein to any specific commercial product, process, or service by trade name, trademark, manufacturer, or otherwise does not necessarily constitute or imply its endorsement, recommendation, or favoring by the United States Government or any agency thereof. The views and opinions of authors expressed herein do not necessarily state or reflect those of the United States Government or any agency thereof.

\author{
SUBJECT DESCRIPTORS \\ Plutonium \\ Plutonium Peroxide \\ Plutonium Oxalate \\ Plutonium Fluoride \\ Plutonium Carbonate \\ Plutonium Hydroxide \\ Precipitation \\ Particle Size Distribution \\ Crystal Structure
}
ROCKWELL INTERNATIONAL
ENERGY SYSTEMS GROUP ROCKY FLATS PLANT
P.O. BOX 464
GOLDEN, COLORADO $80402-0464$

Prepared under Contract DE-AC04-76DP03533

for the

Albuquerque Operations Office

U.S. Department of Energy 
RFP-3589 


\section{ONTENTS}

Abstract $\ldots \ldots \ldots \ldots \ldots \ldots \ldots \ldots \ldots \ldots \ldots \ldots \ldots \ldots \ldots \ldots, 1$

Introduction $\ldots \ldots \ldots \ldots \ldots \ldots \ldots \ldots \ldots \ldots \ldots \ldots \ldots \ldots \ldots \ldots \ldots$

Background Literature Survey $\ldots \ldots \ldots \ldots \ldots \ldots \ldots \ldots \ldots \ldots \ldots$

Plutonium Peroxide Precipitation ..................... 1

Precipitation of Plutonium(III) Fluoride $\ldots \ldots \ldots \ldots \ldots \ldots \ldots \ldots, 2$

Plutonium(IV) Oxalate Precipitation. ................. 2

Plutonium(III) Oxalate Precipitation. .................. 4

Precipitation of Plutonium Hydroxide $\ldots \ldots \ldots \ldots \ldots \ldots \ldots \ldots \ldots$

Experimental. ............................... 5

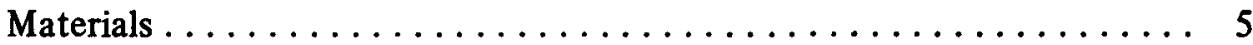

Equipment and Procedures $\ldots \ldots \ldots \ldots \ldots \ldots \ldots \ldots \ldots \ldots, 6$

Results and Discussion $\ldots \ldots \ldots \ldots \ldots \ldots \ldots \ldots \ldots \ldots \ldots, 8$

Conclusion and Recommendations $\ldots \ldots \ldots \ldots \ldots \ldots \ldots \ldots \ldots \ldots$

References................................ 11

Illustrations................................... 13

(Figures 1 through 14) 
RFP-3589

\section{ACKNOWLEDGEMENT}

The authors thank J. D. Navratil for his helpful suggestions. 


\title{
LABORATORY-SCALE EVALUATIONS OF
}

\section{ALTERNATIVE PLUTONIUM PRECIPITATION METHODS}

\author{
Larry L. Martella, Mark T. Saba, and Georgianne K. Campbell
}

\begin{abstract}
Plutonium(III), (IV), and (VI) carbonate; plutonium(III) fluoride; plutonium(III) and (IV) oxalate; and plutonium(IV) and (VI) hydroxide precipitation methods were evaluated for conversion of plutonium nitrate anion-exchange eluate to a solid, and compared with the current plutonium peroxide precipitation method used at Rocky Flats. Plutonium(III) and (IV) oxalate, plutonium(III) fluoride, and plutonium(IV) hydroxide precipitations were the most effective of the alternative conversion methods tested because of the larger particle-size formation, faster filtration rates, and the low plutonium loss to the filtrate. These were found to be as efficient as, and in some cases more efficient than, the peroxide method.
\end{abstract}

\section{INTRODUCTION}

Aqueous processing of plutonium at Rocky Flats normally yields a product in nitric acid solution. Further processing requires conversion of the plutonium nitrate solution to a solid form by a precipitation process.

Plutonium-peroxide precipitation was chosen as a solid conversion process at Rocky Flats because it has the ability to decontaminate metal impurities without addition of any other major impurities to the product. However, this decision was based on the processing procedures and equipment capabilities in Building 771. The precipitation feed solution for Building 771 is a mixture of anioncolumn eluate and plutonium oxide-dissolution solution which contains impurities. The new plutonium recovery facility, Building 371 , will process all scrap through an anion exchange process that essentially removes all major impurities and produces a pure plutonium nitrate solution.
The major chemical disadvantages of the plutonium peroxide precipitation process are: (1) peroxide can decompose violently in the presence of certain metal impurities such as iron, copper, and manganese; (2) the precipitate is not stable and often decomposes; (3) filtrate losses are higher than most other precipitation processes; and (4) halogens and nitrates are carried in the crystal lattice.

The major mechanical disadvantages of the plutonium-peroxide precipitation process at Rocky Flats are: (1) rigid control of the peroxide addition is essential, (2) refrigeration of the feed is required to prevent peroxide decomposition, and (3) decomposition of the plutonium peroxide can adversely affect filtration and may allow plutonium to escape into vacuum lines.

A literature survey follows which summarizes some of the work performed on the major plutoniumprecipitation methods prior to this work. The survey summarizes plutonium-precipitation methods tested under varying circumstances on plutonium solutions produced from several aqueous processes, such as cation exchange, anion exchange, and Purex solvent-extraction processing. Since the peroxide precipitation process requires rigid control of the process variables for success and because purification is no longer required, alternative precipitation methods may be more efficient for solid conversion. This report is a systematic comparison of those major plutonium precipitation methods on anion-exchange eluate produced at Rocky Flats.

\section{BACKGROUND LITERATURE SURVEY}

\section{Plutonium Peroxide Precipitation}

The plutonium-peroxide precipitation process at Rocky Flats has been described by Miner and 
others. ${ }^{1-4}$ An extensive literature survey is presented by Greinetz and Sperry ${ }^{5}$ describing plutonium-peroxide precipitation methods, both past and present, for all major plutonium processing plants. Parameters essential for successful plutonium peroxide precipitation are described in the following paragraphs.

Plutonium nitrate feed solution ( $\sim 20$ to $100 \mathrm{~g} / \mathrm{l}$ $\mathrm{Pu}$ ) is adjusted to $\sim 4 M \mathrm{HNO}_{3}$ because at acidities less than $2 M$ an undesirable colloidal face-centered cubic-phase precipitate is formed. At acidities greater than $2 M$, a hexagonal-phase precipitate is formed that is more dense and easily filtered. Plutonium peroxide is soluble at acidities greater than $5 M$. Precipitate formation is also dependent upon peroxide addition and mixing. A slow and uniform initial peroxide addition $(3 \mathrm{l} / \mathrm{hr})$, along with slow mixing, forms a more stable, easily filtered precipitate. For completeness of precipitation, a several-fold excess peroxide-to-plutonium ratio beyond stoichiometric is required. Rocky Flats production adds at least an excess of 10 moles $\mathrm{H}_{2} \mathrm{O}_{2} / \mathrm{mol} \mathrm{Pu}$ using a $35 \%$ solution of $\mathrm{H}_{2} \mathrm{O}_{2}$ at 10 liter/hour.

Sulfate $(0.05 M)$ is sometimes added to the feed to aid in coagulating the colloids present in a cubic-phase precipitate, which improves filterability. ${ }^{6}$ However, sulfate present in a predominantly hexagonal-phase precipitate alters the efficiency of the fluorination cycle by requiring higher temperatures to drive off the sulfate and decreases the density of the resulting plutonium tetrafluoride.

During precipitation the temperature of the solution is cooled to less than $15^{\circ} \mathrm{C}$ to prevent catalytic decomposition of peroxide caused by metallic impurities.

The precipitate cake remaining after filtration is washed with $0.35 M \mathrm{HNO}_{3}$, then calcined at $450{ }^{\circ} \mathrm{C}$ for 2 hours to convert to an oxide. The peroxide in the filtrate solution is destroyed by boiling while the oxide is fluorinated, then reduced to a metal with calcium.

Table 1 summarizes the advantages and disadvantages of the peroxide-precipitation process, as well as the other precipitation processes surveyed, as described in the following paragraphs.

\section{Precipitation of Plutonium(III) Fluoride}

The plutonium trifluoride process was developed at the Savannah River Plant. ${ }^{7}$ The trifluorideprecipitation process normally follows a cation-exchange process that yields plutonium(III) in dilute nitric acid. Optimum feeds contain 30 to $70 \mathrm{~g} / \ell$ plutonium in 4 to $5 M$ nitric acid. ${ }^{8}$ Sulfamic acid $(0.2 M)$ can be added to this solution to reduce the rate of plutonium(III) oxidation to (IV) by reacting rapidly with nitrous acid. ${ }^{8}$ Ascorbic acid can also be used to reduce and hold plutonium in the trivalent state. ${ }^{8,9}$

The general trifluoride-precipitation equation may be written as $\mathrm{Pu}\left(\mathrm{NO}_{3}\right)_{3}+3 \mathrm{HF} \rightarrow \mathrm{PuF}_{3} \downarrow+3 \mathrm{HNO}_{3}$. Large crystal formation occurs when adding plutonium(III) nitrate and 2.7 to $4 M$ hydrofluoric acid simultaneously into a first-stage precipitation vessel at a controlled rate of residence $(\sim 5 \mathrm{~min}) .{ }^{9}$ Controlled agitation ( $\sim 2$ to $5 \mathrm{ft} / \mathrm{sec}$ blade-tip speed) is essential so as not to produce a finely divided precipitate or local concentration gradients due to minimum agitation. ${ }^{9}$ In order to produce sufficient crystal growth and easy filtration, an $\mathrm{HNO}_{3} / \mathrm{HF}$ ratio greater than six is required in the first stage.

The precipitation cycle is completed by overflowing the slurry into a second-stage vessel where sufficient $\mathrm{HF}$ is added to lower the $\mathrm{HNO}_{3} / \mathrm{HF}$ ratio to three or less. The precipitate is removed, filtered, and washed with dilute $\mathrm{HF}(\sim 0.8 M)$ to remove $\mathrm{HNO}_{3}$ that can slowly oxidize the trifluoride. ${ }^{9}$ The precipitate is then air-dried and is eventually reduced to a metal by one of three described procedures. ${ }^{7}$ Typical yields of the three methods range from 95 to $99 \%$. See Table 1 for advantages and disadvantages.

\section{Plutonium(IV) Oxalate Precipitation}

The plutonium(IV) oxalate precipitation process was developed at Hanford Atomic Products Operation, Richland, Washington. ${ }^{10}$ An extensive literatue survey describing three plutonium(IV) oxalate precipitation methods is presented by Greinetz and Neal. ${ }^{11}$ Oxalic acid is added to plutonium nitrate feed (direct strike), plutonium 
RFP-3589

TABLE 1. Advantages and Disadvantages of Plutonium Conversion Methods

Liquid-to-Solid Conversion Methods

Plutonium(IV) Peroxide

Plutonium(III) Fluoride

Plutonium(IV) Oxalate

Plutonium(III) Oxalate

Plutonium(IV) Hydroxide
Advantages

- Decontaminates americium below current appectable limits at Rocky Flats.

- Highest decontamination from most cation impurities of all precipitation processes.

- $\mathrm{H}_{2} \mathrm{O}_{2}$ does not add other impurities to the stream.

- $\mathrm{H}_{2} \mathrm{O}_{2}$ is readily destroyed by boiling.

- Optimal particle size formation for successive flourination.

- Fair decontamination of most impurities, including iron.

- Produces less quantity of solid precipitate.

- Fast filtration.

- Can be converted to a metal without fluorination.

- Solutions containing high concentrations of metal impurities do not decompose as does peroxide.
Disadvantages

- $\mathrm{H}_{2} \mathrm{O}_{2}$ can decompose violently in the presence of certain metal impurities ( $\mathrm{Fe}, \mathrm{Cu}, \mathrm{Mn}$, etc.), requiring refrigeration during precipitation.

- The precipitate is not stable and decomposes.

- Filtrate losses can sometimes be higher than other processes.

- A high calcination temperature $\left(950^{\circ} \mathrm{C}\right)$ is required to volatilize sulfate, if present.

- Halogens and nitrates are carried in the crystal lattice.

- Al, $\mathrm{Zr}$, and $\mathrm{U}$ are coprecipitated with the plutonium.

- Requires special HF corrosionresistant equipment.

- Because of deposits of plutonium fluoride, equipment must be washed with $\mathrm{Al}\left(\mathrm{NO}_{3}\right)_{3}-\mathrm{HNO}_{3}$.

- If cation-exchange is not used, the plutonium must be reduced to the trivalent state.

- The presence of Pu(IV) will yield high losses to the filtrate. (Solubility of tetrafluoride is $7600 \mathrm{mg} / \mathrm{l}$, compared to $10 \mathrm{mg} / \mathrm{l}$ for trifluoride).

- Two stages of precipitation are required for obtaining discardable filtrates.

- $\mathrm{H}_{2} \mathrm{O}_{2}$ used for valence adjustments can be explosive.

Solids and solutions are more stable than peroxide precipitation.

- Solutions containing high concentrations of metal impurities do not decompose as does peroxide.

- High decontamination of impurities $\mathrm{Fe}, \mathrm{Cr}$, $\mathrm{Al}, \mathrm{Ni}$, and $\mathrm{U}$.

- Most widely used of all conversion methods.

- Fast filtration.

- Capable of producing particles up to $40 \mu \mathrm{m}$.

- Precipitation is performed at room temperature.

- Decontaminates ions of $\mathrm{Fe}, \mathrm{Cr}, \mathrm{Ni}$, and $\mathrm{U}$.

- Requires less process control than other methods.

- Precipitate settles and filters rapidly.

- Supernates containing a low plutonium concentration can be attained.
- Does not decontaminate Am to acceptable limits.

- Carbon content may exceed limits for oxide if calcination and fluorination are incomplete.

- Requires elevated temperature $\left(50^{\circ} \mathrm{C}\right)$ for success.

- Does not decontaminate from cationic impurities, especially Am.

- Two reagents are needed for valence adjustment.

- More oxalic acid is necessary compared to oxalate(IV), thus increasing process volume.

- Forms a gelatinous precipitate difficult to filter.

- Poor purification. 
nitrate is added to oxalic acid (reverse strike), or both streams are added simultaneously (continuous process). The direct-strike method produces larger particles and is therefore more desirable as a conversion method. The plutonium(IV) oxalate precipitation equation may be written as $6 \mathrm{H}_{2} \mathrm{O}+\mathrm{Pu}\left(\mathrm{NO}_{3}\right)_{4}+2 \mathrm{H}_{2} \mathrm{C}_{2} \mathrm{O}_{4} \rightarrow$ $\mathrm{Pu}\left(\mathrm{C}_{2} \mathrm{O}_{4}\right)_{2} \cdot 6 \mathrm{H}_{2} \mathrm{O} \downarrow+4 \mathrm{HNO}_{3}$.

Nitrate feeds prior to precipitation can range from 1 to $300 \mathrm{~g} / \ell \mathrm{Pu}$. The plutonium nitrate feed must contain enough acid to make the final slurry 1.5 to $4.5 \mathrm{M} \mathrm{HNO}_{3}$. Acidities below $1.5 \mathrm{M}$ produce fine particles too small to filter and increase coprecipitation of impurities. Acidities higher than $4.5 \mathrm{M}$ increase plutonium solubility and form a precipitate that is thixotropic. Valence adjustment is essential if plutonium(III) or (VI) are present. A temperature of $50{ }^{\circ} \mathrm{C}$ is required to effectively convert plutonium(III) and (VI) if hydrogen peroxide is used. Incomplete valence conversion increases plutonium filtrate losses.

For precipitation, an excess of $0.1 \mathrm{M} \mathrm{H}_{2} \mathrm{C}_{2} \mathrm{O}_{4}$ greater than stoichiometric is necessary. Oxalic acid less than $0.05 \mathrm{M}$ and greater than $0.2 \mathrm{M}$ in excess increase plutonium solubility. Oxalic acid should be added over a period of 30 to 90 minutes at a temperature of $50{ }^{\circ} \mathrm{C}$. A fast addition produces small particles that will not filter. A low temperature $\left(20^{\circ} \mathrm{C}\right)$ produces small particles, and high temperature $\left(75^{\circ} \mathrm{C}\right)$ causes a gummy precipitate to be formed that will not dry. The $50{ }^{\circ} \mathrm{C}$ temperature of the precipitate should be maintained through digestion ( 1 hour), then chilled to at least $35^{\circ} \mathrm{C}$ over a period of 1.5 hours. Agitation in the precipitation vessel should be minimal to prevent large particle breakup.

After filtration, the precipitate should be washed with $0.05 \mathrm{M} \mathrm{H}_{2} \mathrm{C}_{2} \mathrm{O}_{4}(20 \mathrm{~g}$ wash/gram $\mathrm{Pu}$ in cake). Nitric acid up to $4 M$ can be used as a substitute for the water wash. The plutonium oxalate cake can either be fluorinated directly or calcined to an oxide at $300{ }^{\circ} \mathrm{C}$, then fluorinated at a temperature greater than calcination, not exceeding $480^{\circ} \mathrm{C}$. Carbon removal during calcination can be increased in the presence of air as in a screw calciner. ${ }^{12}$ See Table 1 for plutonium(IV) oxalate precipitation advantages and disadvantages.

\section{Plutonium(III) Oxalate Precipitation}

The plutonium(III) oxalate process was developed at Los Alamos National Laboratory, from 1944 to 1946 , to separate uranium from plutonium. The precipitation methods demonstrated to date are: (1) oxalic acid added to plutonium nitrate feed (direct strike), (2) plutonium nitrate added to oxalic acid (reverse strike), and (3) oxalic acid and plutonium nitrate added simultaneously to the bottom of a vessel, overflowing into a second vessel (simultaneous addition). The direct-strike method is the most widely used for high plutonium concentration feeds and will be discussed here. The Savannah River Plant (SRP) initiated the use of the direct-strike method in 1967. An extensive literature survey describing all the plutonium(III) oxalate precipitation methods is presented by Greinetz and Neal. ${ }^{13}$ The plutonium(III) oxalate precipitation reaction is:

$2 \mathrm{Pu}\left(\mathrm{NO}_{3}\right)_{3}+3 \mathrm{H}_{2} \mathrm{C}_{2} \mathrm{O}_{4}+10 \mathrm{H}_{2} \mathrm{O} \rightarrow$ $\mathrm{Pu}_{2}\left(\mathrm{C}_{2} \mathrm{O}_{4}\right)_{3} \cdot 10 \mathrm{H}_{2} \mathrm{O} \downarrow+6 \mathrm{HNO}_{3}$.

Nitrate feed can range from 5 to $100 \mathrm{~g} / \mathrm{\ell} \mathrm{Pu}$, as demonstrated on a laboratory scale by Porter and Symonds at SRL. ${ }^{14}$ A feed of $1 M \mathrm{HNO}_{3}$ or less is adjusted for valence with ascorbic acid and stabilized with either hydrazine or sulfamic acid $(0.05 M)$. A stoichiometric amount of ascorbic acid is added plus a $0.03 M$ excess to reduce plutonium to plutonium(III). A 10-minute mixing is required for both valence reduction and stabilization. A stoichiometric amount of $1 M$ oxalic acid plus $0.2 M$ excess is added over 30 to 45 minutes and digested for 30 minutes at room temperature. Filtration is normally performed in a medium-porosity, stainless steel, fritted filter. The oxalate-precipitate cake is then washed with 3 cake-volumes of 0.5 to $1 M \mathrm{HNO}_{3}-0.2 M$ oxalic acid.

The precipitate containing 25 to $30 \mu \mathrm{m}$ particles is air-dried at $110^{\circ} \mathrm{C}$ for 3 hours to prevent agglomerate formation, then calcined at $600{ }^{\circ} \mathrm{C}$. The oxide produced is again fluorinated and 
reduced to metal. Advantages and disadvantages are listed in Table 1.

\section{Precipitation of Plutonium Hydroxide}

Plutonium hydroxide precipitation was used at Rocky Flats in the 1950's to precipitate plutonium from analytical laboratory waste. ${ }^{15}$ The plutonium was precipitated by adding solid sodium hydroxide pellets to a 4- $\ell$ bottle of plutonium laboratory waste solution. The supernate was decanted from the top of the vessel after the precipitate settled. The precipitate was then filtered to dryness which required an extensive period of time.

Early laboratory scale results at Los Alamos National Laboratory showed that low plutonium concentrations $\left(4.0 \times 10^{-3} \mathrm{~g} / \ell\right)$ in the supernate could be attained from the plutonium hydroxide precipitation procedure. ${ }^{16}$ Prior to the advent of anion-exchange technology, early production procedures (1947) at Los Alamos utilized successive hydroxideprecipitation methods for recovery of plutonium(III) or (IV). ${ }^{17}$

The procedure used at that time was based on the mixture of impurities in the waste solution to be precipitated. Ammonium hydroxide was used to remove gross amounts of magnesium and calcium, and sodium hydroxide was used to remove amphoteric impurities such as aluminum and chromium. Ammonium hydroxide was added to precipitate the plutonium at a pH of 5 to 6 , while sodium hydroxide was added to a $\mathrm{pH}>8$ to redissolve the aluminum. Note that the plutonium precipitated by ammonium hydroxide is redissolved prior to precipitating with sodium hydroxide. Nitrate feeds containing plutonium(III) were processed similar to plutonium(IV). Plutonium(III) oxidizes rapidly to (IV) after precipitation.

Plutonium(VI) compounds precipitated with various alkali metal hydroxides have been characterized. ${ }^{18}$ However, evaluations such as filtration, particle size, and supernate plutonium loss, have still to be investigated. Advantages and disadvantages of the hydroxide precipitation process are listed in Table 1.

The literature survey above was utilized to determine process parameters in the plutonium precipitation tests that follow. Plutonium feed solution produced by anion exchange was used for all the tests. This consistency of the feed source made comparison of the results more meaningful.

\section{EXPERIMENTAL}

\section{Materials}

Plutonium nitrate feed used in these tests was obtained from Recovery Operations after purification by anion exchange. The plutonium concentrations of the three major feed-stock solutions for the alternative precipitation methods were $55.0 \mathrm{~g} / \ell \mathrm{Pu}$ in $1.3 M \mathrm{HNO}_{3}, 44.5 \mathrm{~g} / \ell \mathrm{Pu}$ in $3.9 M \mathrm{HNO}_{3}$, and $37.0 \mathrm{~g} / \ell \mathrm{Pu}$ in $0.9 M \mathrm{HNO}_{3}$. The 44.5 and $37.0 \mathrm{~g} / \mathrm{l} \mathrm{Pu}$ feed solutions were made from the $55.0 \mathrm{~g} / \mathrm{l} \mathrm{Pu}$ stock feed. Elemental impurity analysis of the stock feed is shown in Table 2.

The stock feed used for the peroxide precipitation comparison tests was $57.4 \mathrm{~g} / \ell \mathrm{Pu}$ in $4.0 \mathrm{M} \mathrm{HNO}_{3}$. Even though the process methods differed, the batching for each test was held constant at $5 \mathrm{~g}$ plutonium.

Ascorbic acid was obtained from Sharpe Chemical Company, Burbank, California. Oxalic acid was supplied by Fisher Scientific, Fairlawn, New Jersey, and was $>99 \%$ pure. Hydrazine was obtained from Fairmount Chemical Company, New Jersey, as a $35 \%$ solution. Hydrofluoric acid (HF) was supplied by Allied Chemical, Morristown, New Jersey, as a $48 \%$ solution. Potassium carbonate $\left(\mathrm{K}_{2} \mathrm{CO}_{3}\right)$ was obtained from J. T. Baker Chemical Company, Phillipsburg, New Jersey, and was 99\% pure. Hydrogen peroxide $\left(\mathrm{H}_{2} \mathrm{O}_{2}\right)$ was commercial grade $35 \mathrm{wt} \% \mathrm{H}_{2} \mathrm{O}_{2}$. All other reagents were reagent grade and used as received. 
TABLE 2. Elemental Impurities in the Stock Feed

\begin{tabular}{|c|c|c|c|}
\hline Element & Analysis & Element & Analysis \\
\hline $\mathbf{P u}$ & $55 \mathrm{~g} / \mathrm{\ell}^{\mathrm{a}}$ & $\mathbf{M g}$ & $<1 \mu \mathrm{g} / \mathrm{m} \ell$ \\
\hline Am & $1.84 \times 10^{-3} \mathrm{~g} / \mathrm{e}^{\mathrm{b}}$ & Mn & $2 \mu \mathrm{g} / \mathrm{ml}$ \\
\hline $\mathbf{H}^{+}$ & $1.3 \mathrm{Eq} / \ell$ & Mo & $<2 \mu \mathrm{g} / \mathrm{m} \ell$ \\
\hline $\mathbf{A g}$ & $<1 \mu \mathrm{g} / \mathrm{m} \ell^{\mathrm{c}}$ & $\mathrm{Na}$ & $<100 \mu \mathrm{g} / \mathrm{ml}$ \\
\hline $\mathrm{Al}$ & $<100 \mu \mathrm{g} / \mathrm{m} \ell$ & $\mathrm{Nb}$ & $<10 \mu \mathrm{g} / \mathrm{m} \ell$ \\
\hline As & $<10 \mu \mathrm{g} / \mathrm{ml}$ & $\mathrm{Ni}$ & $<10 \mu \mathrm{g} / \mathrm{m} \ell$ \\
\hline B & $<1 \mu \mathrm{g} / \mathrm{ml}$ & $\mathbf{P}$ & $<200 \mu \mathrm{g} / \mathrm{ml}$ \\
\hline $\mathrm{Ba}$ & $<1 \mu \mathrm{g} / \mathrm{m \ell}$ & $\mathrm{Pb}$ & $<10 \mu \mathrm{g} / \mathrm{m} \ell$ \\
\hline $\mathrm{Be}$ & $0.2 \mu \mathrm{g} / \mathrm{ml}$ & $\mathbf{R b}$ & $<100 \mu \mathrm{g} / \mathrm{m} \ell$ \\
\hline $\mathrm{Bi}$ & $<10 \mu \mathrm{g} / \mathrm{ml}$ & $\mathrm{Sb}$ & $<10 \mu \mathrm{g} / \mathrm{m} \ell$ \\
\hline $\mathrm{Ca}$ & $6 \mu \mathrm{g} / \mathrm{m} \ell$ & $\mathbf{S r}$ & $<100 \mu \mathrm{g} / \mathrm{ml}$ \\
\hline $\mathrm{Cd}$ & $<200 \mu \mathrm{g} / \mathrm{m} \ell$ & Sn & $<2 \mu \mathrm{g} / \mathrm{m} \ell$ \\
\hline $\mathrm{Ce}$ & $<100 \mu \mathrm{g} / \mathrm{ml}$ & $\mathrm{Te}$ & $<20 \mu \mathrm{g} / \mathrm{m} \ell$ \\
\hline Co & $<10 \mu \mathrm{g} / \mathrm{m} \ell$ & $\mathrm{Ta}$ & $<10 \mu \mathrm{g} / \mathrm{m} \ell$ \\
\hline $\mathrm{Cr}$ & $<2 \mu \mathrm{g} / \mathrm{m} \ell$ & Th & $<100 \mu \mathrm{g} / \mathrm{m} \ell$ \\
\hline Cs & $<200 \mu \mathrm{g} / \mathrm{m} \ell$ & $\mathrm{Ti}$ & $<2 \mu \mathrm{g} / \mathrm{m} \ell$ \\
\hline $\mathrm{Cu}$ & $<1 \mu \mathrm{g} / \mathrm{ml}$ & $\mathbf{T 1}$ & $<100 \mu \mathrm{g} / \mathrm{ml}$ \\
\hline $\mathrm{Fe}$ & $<2 \mu \mathrm{g} / \mathrm{m} \ell$ & $\mathbf{U}$ & $<100 \mu \mathrm{g} / \mathrm{m} \ell$ \\
\hline $\mathrm{Ga}$ & $<200 \mu \mathrm{g} / \mathrm{m} \ell$ & $\mathbf{V}$ & $<1 \mu \mathrm{g} / \mathrm{m} \ell$ \\
\hline $\mathrm{Ge}$ & $<2 \mu \mathrm{g} / \mathrm{ml}$ & W & $<200 \mu \mathrm{g} / \mathrm{ml}$ \\
\hline $\mathrm{Hg}$ & $<2 \mu \mathrm{g} / \mathrm{ml}$ & $\mathrm{Zn}$ & $<100 \mu \mathrm{g} / \mathrm{m \ell}$ \\
\hline $\mathbf{K}$ & $20 \mu \mathrm{g} / \mathrm{m} \ell$ & $\mathrm{Zr}$ & $<10 \mu \mathrm{g} / \mathrm{m} \ell$ \\
\hline $\mathbf{L i}$ & $<200 \mu \mathrm{g} / \mathrm{m} \ell$ & & \\
\hline
\end{tabular}

a. Plutonium concentration determined by radiometric counting.

b. Americium concentration determined by gamma spectrometry.

c. Elemental analysis determined by emission spectroscopy ( $<$ values are below detectable limits).

\section{Equipment and Procedures}

The plutonium for all the tests was precipitated in a 500-m $\ell$ beaker. The beaker was placed on a combination hotplate/magnetic stirrer using a Teflon® stir-bar for tests requiring heat or mixing. A $25-\mathrm{m} \ell$ buret was used to deliver precipitating agent or feed to the beaker when required. After the addition of precipitating agent, the plutoniumprecipitate slurry was filtered in a Millipore ${ }^{\circledR}$ funnel using Whatman $\circledast 41$ filter paper. A $150-\mathrm{m} \ell$ wash solution, whose composition depended upon the precipitating agent, was poured over the precipitate prior to drying. Filtration and washing times were recorded for each test.

The filtrate and wash of each test were collected, combined, and analyzed for plutonium concentration. The particles from the slurries of each test were analyzed for crystal structure by $x$-ray diffraction (XRD) and for particle size by photomicrography. Plutonium oxidation states were confirmed by UV-visible spectrophotometric analyses performed with a Cary Model 14 spectrophotometer.

Plutonium peroxide precipitations were conducted to compare the various alternative methods with the current method used at Rocky Flats. Plutonium stock feed of $57 \mathrm{~g} / \mathrm{l} \mathrm{Pu}$ in $4.0 \mathrm{M} \mathrm{HNO}_{3}$ was precipitated with $35 \mathrm{wt} \% \mathrm{H}_{2} \mathrm{O}_{2}$. The hydrogen peroxide was added slowly $(1 \mathrm{ml} / \mathrm{min})$ at room temperature $\left(22\right.$ to $\left.24{ }^{\circ} \mathrm{C}\right)$ until a $19.7: 1$ mole ratio was achieved with the plutonium. Each slurry was digested at room temperature for 30 minutes and the precipitates were filtered and washed with water. Sulfate was not added to the feed prior to precipitation for these tests. 
For trifluoride precipitations, 1.5 moles of ascorbic acid per mole of plutonium were added to the stock feed (44.5 g/ $\left.\ell \mathrm{Pu}-3.9 \mathrm{M} \mathrm{HNO}_{3}\right)$ to reduce $\mathrm{Pu}$ (IV) to the (III) oxidation state. A milliliter of hydrazine was added to the feed to remove any nitrous acid and to allow complete reduction to $\mathrm{Pu}(\mathrm{III})$. The plutonium(III) nitrate and $4 M \mathrm{HF}$ were added to the beaker simultaneously at rates of $5 \mathrm{ml} / \mathrm{min}$ and $1.3 \mathrm{ml} / \mathrm{min}$, respectively, until the mole ratio of fluoride-to-plutonium reached $6: 1$. Each precipitate slurry was digested for 30 minutes with minimal agitation, then filtered. The precipitates were washed with $0.8 M \mathrm{HF}$ prior to final filtration.

The plutonium(III) oxalate precipitation procedure consisted of adjusting the stock feed to $0.8 \mathrm{M}$ in $\mathrm{HNO}_{3}$ with $0.35 M \mathrm{HNO}_{3}$, yielding a solution containing $32.61 \mathrm{~g} / \ell$ plutonium. The feed was then adjusted to $0.05 \mathrm{M}$ in hydrazine to remove any nitrous acid present in the stock solution. Ascorbic acid was added to the feed in a 1:1 mole ratio with the plutonium, and mixed at room temperature to reduce the Pu(IV) to the (III) oxidation state. The plutonium was then precipitated with $1 M$ oxalic acid over a period of 30 to 40 minutes to yield slurry mixtures in either a $3: 2$ mole ratio or a $0.25 \mathrm{M}$ oxalic acid excess. Each precipitate slurry was digested at room temperature $\left(22\right.$ to $24^{\circ} \mathrm{C}$ ) for 30 minutes and then quickly filtered with a $0.5 \mathrm{M} \mathrm{HNO}_{3}-0.2 \mathrm{M}$ oxalic acid wash.

For plutonium(IV) oxalate, the stock feed (55 $\mathrm{g} / \mathrm{l} \mathrm{Pu}-1.3 \mathrm{M} \mathrm{HNO}_{3}$ ) was adjusted to $4.09 \mathrm{M}$ in $\mathrm{HNO}_{3}$ with concentrated nitric acid lowering the plutonium concentration to $45.78 \mathrm{~g} / \ell$. The adjusted feed solution was heated to $50{ }^{\circ} \mathrm{C}$ and precipitated with $1 M$ oxalic acid. The oxalic acid was added slowly and the final mole ratios of oxalate-to-plutonium varied from 2.5:1 to 4:1. Each plutonium-oxalate slurry was digested for 30 minutes and cooled prior to filtration. The precipitates were washed with $2.0 M \mathrm{HNO}_{3}$ and filtered.

Plutonium(III) carbonate precipitation was accomplished using the stock feed $(55 \mathrm{~g} / \ell$ $\mathrm{Pu}-1.3 \mathrm{M} \mathrm{HNO}_{3}$ ) with plutonium in the (III) oxidation state. As in the previously described procedure for plutonium(III) oxalate, the feed was made $0.05 M$ in hydrazine to remove any nitrous acid and the plutonium(IV) was reduced with ascorbic acid (1:1 mole ratio). After heating the feed to a temperature of 60 to $80{ }^{\circ} \mathrm{C}$, potassium carbonate $\left(2 \mathrm{M} \mathrm{K}_{2} \mathrm{CO}_{3}\right)$ was added slowly $(1 \mathrm{ml} /$ min) until a $\mathrm{pH}$ of 6 to 7 was attained. The slurries were digested for 30 minutes and then filtered. The precipitates were washed with water and filtered again.

For plutonium(IV) carbonate precipitations, $100 \%$ plutonium(IV) feed solutions were precipitated using $4 M$ and $2 \mathrm{M} \mathrm{K}_{2} \mathrm{CO}_{3}$ at $80^{\circ} \mathrm{C}$ and $60^{\circ} \mathrm{C}$, respectively. The $\mathrm{pH}$ of the reactions was maintained between 6 to 7 , and the slurries were digested for 30 minutes. The precipitates were washed with water and filtered until dry.

For plutonium(VI) carbonate precipitation, the stock feed was boiled under reflux for 26 hours and precipitated as in the aforementioned process using $2 \mathrm{M} \mathrm{K}_{2} \mathrm{CO}_{3}$. Other attempts to make pure $\mathrm{Pu}(\mathrm{VI})$ feed produced mixtures of $40 \% \mathrm{Pu}(\mathrm{IV})$ and $60 \% \mathrm{Pu}(\mathrm{VI})$ after boiling the stock feed for only 2 and 5 hours. These were precipitated using $4 M \mathrm{~K}_{2} \mathrm{CO}_{3}$.

The final alternative precipitation methods tested were $\mathrm{Pu}(\mathrm{IV})$ and $\mathrm{Pu}(\mathrm{VI})$ hydroxide. Two precipitating agents, potassium hydroxide (1.5M $\mathrm{KOH})$ and sodium hydroxide $(5.0 \mathrm{M} \mathrm{NaOH})$, were added to the stock $\mathrm{Pu}(\mathrm{IV})$ feeds of $55 \mathrm{~g} / \mathrm{\ell} \mathrm{Pu}$ in $3.9 M \mathrm{HNO}_{3}$ and $37 \mathrm{~g} / \ell \mathrm{Pu}$ in $0.9 M \mathrm{HNO}_{3}$, respectively. The $\mathrm{Pu}(\mathrm{VI})$ feeds were prepared by reflux for 36 hours.

The addition rate of the precipitating agent to the feed solution was 1 to $2 \mathrm{~m} \ell / \mathrm{min}$. The Pu(VI) $\mathrm{KOH}$ precipitations were completed at a $\mathrm{pH}$ of 6.5 at room temperature. The Pu(IV) and (VI) $\mathrm{NaOH}$ precipitations were completed at a $\mathrm{pH}$ of 13 at 80 to $85^{\circ} \mathrm{C}$. All the precipitates were washed with water and filtered until dry. There were attempts to precipitate $\mathrm{Pu}(\mathrm{VI})$ with $\mathrm{KOH}$ at a $\mathrm{pH}$ of 10.5; however, these resulted in very little precipitate with high plutonium loss to the filtrates and were abandoned. 


\section{RESULTS AND DISCUSSION}

Table 3 shows the result of all the methods tested.

The table will be referred to in the following paragraphs for evaluation of individual tests performed.

The results of the plutonium-peroxide precipitation tests are shown in Table 3, Runs 1 and 2. Slurry particles in both runs appeared similar, showing good consolidation, with the exception of more smaller particles, less than $5 \mu \mathrm{m}$, in Run 1 . Typical particles are shown in Figure 1. The major crystalline species identified by XRD was hexagonal phase and the minor was cubic. The cubic structure contains three atoms of peroxyoxygen per plutonium atom, whereas the hexagonal structure contains more peroxy-oxygen to plutonium. ${ }^{5}$ Filtration rates were as rapid or faster than any of the alternative precipitation methods tested. Plutonium losses in the filtrates were also comparable to average losses in filtrates of the alternative methods tested.

The plutonium trifluoride $\left(\mathrm{PuF}_{\mathbf{3}}\right)$ data in Table 3 are the results of two different precipitation procedures. In Runs 3 and 5 the feed and HF were

TABLE 3. Precipitation Characteristics

\begin{tabular}{|c|c|c|c|c|c|c|c|}
\hline \multirow[b]{2}{*}{ Run No. } & \multirow[b]{2}{*}{ Precipitation Method } & \multicolumn{2}{|c|}{ Crystal Structure } & \multicolumn{2}{|c|}{$($ dia, $\mu)$} & \multirow{2}{*}{$\begin{array}{l}\text { Time } \\
\mathrm{ml} / \mathrm{min}\end{array}$} & \multirow{2}{*}{$\begin{array}{c}\text { Loss } \\
\mathrm{g} / \mathrm{l} \mathrm{Pu}\end{array}$} \\
\hline & & Major & Minor & Range & Majority & & \\
\hline 1 & Plutonium(IV) Peroxide & $\mathrm{Pu}_{2} \mathrm{O}_{7}^{\mathrm{a}}$ & $\mathrm{Pu}_{2} \mathrm{O}_{7}{ }^{\mathrm{b}}$ & $3-40$ & $>20$ & 600 & 0.0804 \\
\hline 2 & Plutonium(IV) Peroxide & $\mathrm{Pu}_{2} \mathrm{O}_{7}{ }^{\mathrm{a}}$ & $\mathrm{Pu}_{2} \mathrm{O}_{7}^{\mathrm{b}}$ & $3-40$ & $>20$ & 529 & 0.15 \\
\hline 3 & Plutonium Trifluoride & $\mathrm{PuF}$, & none & $3-50$ & $5-15$ & 285 & 0.22 \\
\hline 4 & Plutonium Trifluoride & $\mathrm{PuF}_{\mathbf{3}}^{\mathrm{C}}$ & (possible) $\mathrm{PuF}_{4}$ & $<1-15$ & $<1-2$ & 76 & 0.26 \\
\hline 5 & Plutonium Trifluoride & $\mathrm{PuF}_{\mathrm{s}}$ & none & $2-30$ & $10-25$ & 326 & 0.39 \\
\hline 6 & Plutonium(III) Oxalate & $\mathrm{Pu}_{2}\left(\mathrm{C}_{2} \mathrm{O}_{4}\right)_{3} \cdot 10 \mathrm{H}_{2} \mathrm{O}$ & none & $5->40$ & $25-30$ & 172 & 0.0274 \\
\hline 7 & Plutonium(III) Oxalate & $\mathrm{Pu}_{2}\left(\mathrm{C}_{2} \mathrm{O}_{4}\right)_{3} \cdot 10 \mathrm{H}_{2} \mathrm{O}$ & none & $5->40$ & $20-40$ & 220 & 0.0217 \\
\hline 8 & Plutonium(IV) Oxalate & $\mathrm{Pu}\left(\mathrm{C}_{2} \mathrm{O}_{4}\right)_{2} \cdot 6 \mathrm{H}_{2} \mathrm{O}$ & none & $2-30$ & 10 & 71 & 0.28 \\
\hline 9 & Plutonium(IV) Oxalate & $\mathrm{Pu}\left(\mathrm{C}_{2} \mathrm{O}_{4}\right)_{2} \cdot 6 \mathrm{H}_{2} \mathrm{O}$ & none & $2-35$ & $<15$ & 586 & 0.21 \\
\hline 10 & Plutonium(IV) Oxalate & $\mathrm{Pu}\left(\mathrm{C}_{2} \mathrm{O}_{4}\right)_{2} \cdot 6 \mathrm{H}_{2} \mathrm{O}$ & none & $5-30$ & $15-20$ & 421 & 0.15 \\
\hline 11 & Plutonium(IV) Oxalate & $\mathrm{Pu}\left(\mathrm{C}_{2} \mathrm{O}_{1}\right)_{2} \cdot 6 \mathrm{H}_{2} \mathrm{O}$ & none & $5-40$ & $25-30$ & 457 & 0.11 \\
\hline 12 & Plutonium(III) Carbonate & Amorphous & - & $<1$ & $<1$ & d & 0.0594 \\
\hline 13 & Plutonium(III) Carbonate & Amorphous & - & $<1$ & $<1$ & d & 0.26 \\
\hline \multirow[t]{2}{*}{14} & Plutonium(IV) Carbonate & $50 \% \mathrm{PuO}_{2}{ }^{\mathrm{C}}$ & & & & & \\
\hline & & $50 \% \mathrm{KPuO}_{2} \mathrm{CO}_{3}$ & - & $<1->30$ & $1-15$ & 1.6 & 0.00218 \\
\hline 15 & Plutonium(IV) Carbonate & $\mathrm{PuO}_{2} \mathrm{c}$ & none & $<1->30$ & $5-25$ & 2 & 0.00383 \\
\hline 16 & $60 \%$ Plutonium(VI)-(IV) Carbonate & $\mathrm{PuO}_{2} \mathrm{CO}_{3}$ & none & $<1-40$ & $<3$ & 1.6 & 0.00153 \\
\hline 17 & $60 \%$ Plutonium(VI)-(IV) Carbonate & $\mathrm{KPuO}_{2} \mathrm{CO}_{3}$ & $\mathrm{PuO}_{2} \mathrm{CO}_{3}$ & $1-50$ & $2-10$ & 4.5 & 0.79 \\
\hline 18 & Plutonium(VI) Carbonate & $\mathrm{PuO}_{2} \mathrm{CO}_{8}$ & $\mathrm{KPuO}_{2} \mathrm{CO}_{3}$ & $<1$ & $<1$ & d & 0.0938 \\
\hline 19 & Plutonium(VI) Carbonate & $\mathrm{PuO}_{2} \mathrm{CO}_{8}$ & $\mathrm{KPuO}_{2} \mathrm{CO}$, & $<1-5$ & $1-5$ & d & 0.0173 \\
\hline 20 & Plutonium(VI) Hydroxide (KOH) & $\mathrm{PuO}_{2} \mathrm{C}$ & none & $<1-50$ & $<2$ & 1.5 & 8.10 \\
\hline 21 & Plutonium(VI) Hydroxide (KOH) & $\mathrm{PuO}_{2}{ }^{\mathrm{C}}$ & none & $<1-30$ & $<10$ & $\mathrm{~d}$ & 15.3 \\
\hline 22 & Plutonium(IV) Hydroxide (NaOH) & $\mathrm{PuO}_{2}{ }^{\mathrm{C}}$ & none & $5->100$ & $10-50$ & 36 & 0.00724 \\
\hline 23 & Plutonium(VI) Hydroxide $(\mathrm{NaOH})$ & $\mathrm{Na}_{2} \mathrm{Pu}_{2} \mathrm{O}_{7}$ & none & $5-20$ & $5-20^{e}$ & 40 & 2.11 \\
\hline 24 & Plutonium(VI) Hydroxide (NaOH) & $\mathrm{Na}_{2} \mathrm{Pu}_{2} \mathrm{O}_{7}$ & none & $3-30$ & $3-10$ & 40 & 2.15 \\
\hline
\end{tabular}

a. $\mathrm{Pu}$ peroxide hexagonal phase.

b. Pu peroxide cubic phase.

c. Poor crystallinity.

d. Requires a filtration time greater than 6 hours; actual times are unknown because filtration was continued overnight.

e. Equally distributed between 5 and $20 \mu \mathrm{m}$. 
added simultaneously, whereas Run 4 was performed as a batch operation where bulk quantities of $\mathrm{HF}$ were added twice. The results of Run 4 show smaller particle-size formation and $\mathrm{PuF}_{3}$ of poor crystallinity, with the possible presence of plutonium tetrafluoride $\left(\mathrm{PuF}_{4}\right)$. Typically, for Runs 3 and 5 the digested slurry filtered quickly and showed a very strong crystalline plutonium trifluoride XRD pattern with no extraneous peaks. The majority of particles were larger, averaging $15 \mu \mathrm{m}$; more uniform in size; and more consolidated and discrete than Run 4. A photomicrograph typical of Runs 3 and 5 is shown in Figure 2. Photomicrographs taken of these slurries indicated that some dissolution of the particles occurred, demonstrating the importance of immediate filtration after precipitation. In general, plutonium trifluoride precipitation produced the smallest solids-to-liquid ratio of all the methods tested.

The particles from the $\mathrm{Pu}$ (III) oxalate slurries of Runs 6 and 7 were among the largest and best consolidated of all the precipitation tests. The particles settled rapidly, filtered easily, and the plutonium loss in the filtrate was very low. X-ray diffraction results identified the precipitates as $\mathrm{Pu}_{2}\left(\mathrm{C}_{2} \mathrm{O}_{4}\right)_{3} \cdot 10 \mathrm{H}_{2} \mathrm{O}$, a plutonium(III) oxalate having a monoclinic structure.

Figure 3 shows Run 6 Pu(III) oxalate slurry particles. The majority ranged from 25 to $30 \mu \mathrm{m}$ in size and appeared as aggregates of smaller geometrically shaped particles resembling Maltese Crosses. In Run 7, Figure 4, there were two types of particles present. The majority were like those found in Run 6; that is, clusters of Maltese Cross forms; however, there were also some dendritic forms present. Both types appeared to be the same crystal structure and compound. The dendritic type tended to form as very large particles, as large as $90 \mu \mathrm{m}$ in size, but the majority of particles which were seen averaged 20 to $40 \mu \mathrm{m}$ in size.

In Runs 8 through 11, Pu(IV) oxalates were precipitated. A triclinc structure was identified for all four tests by XRD as $\mathrm{Pu}\left(\mathrm{C}_{2} \mathrm{O}_{4}\right)_{2} \cdot 6 \mathrm{H}_{2} \mathrm{O}$. The particles from the Run 8 slurry in Figure 5 appear as chains and loosely packed clusters of smaller spheres. The individual spheres ranges in size from 2 to $7 \mu \mathrm{m}$, and the entire particles ranged from 2 to $30 \mu \mathrm{m}$, with the majority at approximately $10 \mu \mathrm{m}$. The particles from Run 9 were more compact and consolidated than those in Run 8 , although more amorphous in shape. Their sizes varied widely, ranging from 2 to $35 \mu \mathrm{m}$, most of which were less than $15 \mu \mathrm{m}$. Like Run 9, particles from Run 10 were more consolidated than Run 8, but showed more uniformity in size and more geometry in shape. Some of the individual crystals within the particles tended to appear somewhat tetragonal. The majority of particles ranged 15 to $20 \mu \mathrm{m}$ in size. In Run 11, Figure 6, particles appeared as groups of tetragonal-shaped crystals. Whole particles were uniform in size, most of which were 25 to $30 \mu \mathrm{m}$ in size.

In Runs 8 through 11 , the particle sizes for each run varied because of the different mole ratios of oxalic acid-to-plutonium used, where the larger ratios resulted in larger particles. Filtration rates were as rapid as in the $\mathrm{Pu}(\mathrm{III})$ oxalate runs, although plutonium loss was somewhat higher.

Particles from the plutonium(III) carbonate slurries in Runs 12 and 13 were colloidal and gelatinous in appearance, and slow to settle and filter. The XRD pattern was amorphous, showing no crystalline species present, and the majority of the particles were submicron with some large agglomerations, as shown in Figure 7. The plutonium loss in the wash and filtrate was minimal, although filtration rates were unreasonably slow.

Although Runs 14 and 15 showed the lowest plutonium loss to the filtrate, the plutonium(IV) precipitates were very slow to settle, and to filter, and the slurries contained a large solids-to-liquid ratio. Run 14 was performed at $80^{\circ} \mathrm{C}$ with $4 M$ $\mathrm{K}_{2} \mathrm{CO}_{3}$ and Run 15 was at $60^{\circ} \mathrm{C}$ and with $2 M$ $\mathrm{K}_{2} \mathrm{CO}_{3}$. The majority of particles from Run 14 ranged between 1 to $15 \mu \mathrm{m}$ and from Run 15 between 5 to $25 \mu \mathrm{m}$. Photomicrographs in Figures 8 and 9 were taken of Runs 14 and 15, respectively, and show their differences in size and in contrast, which relates to their refractive index differences from the slurry media. Run 15 particles appeared gelatinous, while Run 14 particles appeared more crystalline. X-ray diffraction analysis of the slurry particles showed very 
poor crystalline patterns of cubic plutonium(IV) oxide $\left(\mathrm{PuO}_{2}\right)$ for both runs. However, in addition to the $\mathrm{PuO}_{2}$ species, Run 14 also contained an approximately equal quantity of potassium plutonyl(V) carbonate $\left(\mathrm{KPuO}_{2} \mathrm{CO}_{3}\right)$. Although the exact mechanism is unknown for the $\mathrm{Pu}(\mathrm{V})$ formation from $\mathrm{Pu}(\mathrm{IV})$ feed, speculations might suggest disproportionation from the (IV) state to the (VI) state and then back to the (V) state.

Runs 16 and 17, shown in Table 3, are potassium carbonate precipitations of a mixture of $40 \%$ $\mathrm{Pu}(\mathrm{IV})$ and $60 \% \mathrm{Pu}(\mathrm{VI})$ feed, which was the result of an inadequate reflux period. Figure 10 shows the slurry particles from Run 17 , the majority of which were between 1 to $10 \mu \mathrm{m}$. Run 16 particles were mainly less than $3 \mu \mathrm{m}$ in size and were more gelatinous in appearance than Run 17. Particles from Run 16 were identified by XRD as plutonyl carbonate $\left(\mathrm{PuO}_{2} \mathrm{CO}_{3}\right)$, an orthorhombic plutonium(VI) compound. Two species were identified from Run 17 as $\mathrm{KPuO}_{2} \mathrm{CO}_{3}$ in major quantities and $\mathrm{PuO}_{2} \mathrm{CO}_{3}$ in minor amounts. All three XRD patterns showed very high crystallinity. It may be speculated that in Run 17 disproportionation of the $\mathrm{Pu}(\mathrm{VI})$ to $\mathrm{Pu}(\mathrm{V})$ occurred, resulting in the $\mathrm{Pu}(\mathrm{V})$ compound. The formation of plutonium(V) compound from plutonium(VI) had been observed in the past. ${ }^{18}$

Runs 18 and 19 were both $\mathrm{Pu}(\mathrm{VI})$ carbonate precipitations. Slurry particles from Run 18 were submicron in size and appeared gelatinous. In Figure 11, particles from Run 19 were slightly larger, averaging 1 to $5 \mu \mathrm{m}$, and gelatinous in appearance. Although plutonium loss to the filtrate was very low, filtration times for both runs were greater than 6 hours. Two crystalline species were identified by $\mathrm{XRD}$ as $\mathrm{PuO}_{2} \mathrm{CO}_{3}$ (major) and $\mathrm{KPuO}_{2} \mathrm{CO}_{3}$ (minor). Again, the $\mathrm{Pu}(\mathrm{V})$ compound may be due to disproportionation of $\mathrm{Pu}(\mathrm{VI})$ to $\mathrm{Pu}(\mathrm{V})$.

Table 3 shows plutonium(VI) hydroxide-precipitation characteristics for Runs 20 and 21 using $1.54 M \mathrm{KOH}$ as the precipitating agent at a $\mathrm{pH}$ of 6.5. Very little precipitate was formed in these runs, as indicated by the high concentration of plutonium present in the filtrate. Two runs not shown on the table were performed by addition of $1.54 M \mathrm{KOH}$ at a $\mathrm{pH}$ of 10.5 . Because of the inadequate amount of precipitate formed, sampling was not feasible for either run. Slurry particles from Run 21 are shown in Figure 12. The particles from Runs 20 and 21 appeared gelatinous; the former with the majority of particles less than $2 \mu \mathrm{m}$ and the latter having particles less than 10 $\mu \mathrm{m}$. X-ray diffraction results showed poor crystalline patterns for $\mathrm{PuO}_{2}$.

Table 3 , Run 22, shows the results of a test in which $37 \mathrm{~g} / \ell$ plutonium(IV) in $0.9 M \mathrm{HNO}_{3}$ was precipitated with $5 M \mathrm{NaOH}$. Plutonium loss in the filtrate was extremely low and filtration was fast. Figure 13 shows some typical particles from Run 22, some of which appear as fragile-looking plates. Sizes varied from 5 to $>100 \mu \mathrm{m}$. $\mathrm{PuO}_{2}$ was identified by XRD as the only crystalline species present.

Results of tests using $5 M \mathrm{NaOH}$ to precipitate 37 $\mathrm{g} / \ell$ plutonium(VI) in $0.9 \mathrm{M} \mathrm{HNO}_{3}$ are shown in Table 3, Runs 23 and 24. Washing the precipitate with water appeared to dissolve some of the precipitate allowing particles to pass through the filter, explaining the high plutonium loss in the filtrate. A post precipitate formed in the filtrate following the filtration step. Filtration times were somewhat faster than expected from a gelatinous precipitate. In both runs, three types of particles were present, as shown in Figure 14. One type appeared as dense clusters of rosettes, the second type as amorphous crystals, and the third type as rectangular, translucent crystals. The amorphous crystals were more numerous in Run 24. The majority of particles in Run 23 were from 5 to $20 \mu \mathrm{m}$, and in Run 24 from 3 to $10 \mu \mathrm{m}$. The only crystalline species present were identified as sodium diplutonate $\left(\mathrm{Na}_{2} \mathrm{Pu}_{2} \mathrm{O}_{7}\right)$ by XRD.

\section{CONCLUSION AND RECOMMENDATIONS}

A recommendation of any alternative precipitation method for use at Rocky Flats would require further pilot-plant scale evaluations. Furthermore, future investigations would certainly include criteria not dealt with in this report, such as equipment compatability and economic feasibility.

Conclusions for these laboratory scale tests are based on particle size formation, filtration rates, 
and plutonium loss in the filtrate. Of the alternative methods tested, plutonium(III) trifluoride, plutonium(III) and plutonium(IV) oxalate, and plutonium(IV) hydroxide precipitations were effective in all categories, and warrant further investigation. Plutonium(III), (IV), and (VI) carbonate were ineffective because of excessive filtration times and small particle-size formation. Plutonium(VI) hydroxide was inefficient due to plutonium loss in the filtrate and post precipitation in the filtrate. Perhaps the use of a different precipitate wash solution other than water prevent particle dissolution and high filtrate losses.

Plutonium peroxide precipitation, the current method used at Rocky Flats, was as efficient or more efficient than the most effective of the alternative methods tested. Again, this study does not take into consideration other criteria such as chemical stability of the precipitate, safety requirements, and equipment comparisons.

Future laboratory work will include evaluation of thermal denitration as an alternative for oxide conversion at Rocky Flats. The process is especially attractive if the oxide can be directly reduced to a metal without liquid-to-solid precipitation or fluorination steps.

\section{REFERENCES}

1. F. J. Miner and P. G. Hagan, "Rate of Hydrogen Peroxide Decomposition in Nitric Acid Solutions," I\&EC Process Design and Development, 11, p 547, October 1972.

2. P. G. Hagan, P. A. Glover, and F. J. Miner, "Precipitation of Plutonium Peroxide," "Precipitation of Plutonium Peroxide from 20 g/ / Plutonium Solutions," "Plutonium VI in the Plutonium Peroxide Precipitation Process," Research and Ecology Semiannual Progress Report, RFP-2004-A, Dow Chemical U.S.A., Rocky Flats Plant, Golden, Colorado, July through December 1972.

3. P. G. Hagan and F. J. Miner, "Plutonium Peroxide Precipitation and Calcination Studies for the New Plutonium Recovery and Waste Treatment Facility," Chemistry Research and Development Semiannual Progress Report, RFP-2276-A, Dow Chemical
U.S.A., Rocky Flats Plant, Golden, Colorado, January through June 1974.

4. P. G. Hagan, F. J. Miner, and L. L. Martella, "Plutonium Peroxide Precipitation Process," Research and Development Semiannual Progress Report, RFP-2417-A, Rockwell International, Rocky Flats Plant, Golden, Colorado, January through June 1975.

5. R. M. Greinetz and W. E. Sperry, "Plutonium Peroxide Precipitation and Calcination Process for Plutonium Nitrate to Oxide Conversion," RFP-2606, Rockwell International, Rocky Flats Plant, Golden, Colorado, February 2, 1980, and references therein.

6. J. M. Cleveland, Chemistry of Plutonium, First ed., pp 531-534, Gordon and Breach, Science Publishers, Inc., 1970.

7. D. A. Orth, "Plutonium Metal from Trifluoride," in Ind. Eng. Chem., Process Design Develop., 4:28-32 (1965).

8. G. A. Burney and F. W. Tober, "Precipitation of Plutonium Trifluroide," in Ind. Eng. Chem., Process Design Develop., 2:121-127 (1963).

9. Ibid. 6, pp 535-538.

10. J. F. Facer, Jr. and K. M. Harmon, "Precipitation of Plutonium (IV) Oxalate," USAEC Report HW-31186 (Del.), March 30, 1954.

11. R. M. Greinetz and D. M. Neal, "Plutonium (IV) Oxalate Precipitation and Calcination Process for Plutonium Nitrate to Oxide Conversion," RFP-2602, Rockwell International, Rocky Flats Plant, Golden, Colorado, July 26, 1978, and references therein.

12. Ibid. 6, p 530.

13. R. M. Greinetz and D. M. Neal, "Plutonium (III) Oxalate Precipitation and Calcination Process for Plutonium Nitrate to Oxide Conversion," RFP-2603, Rockwell International, Rocky Flats Plant, Golden, Colorado, February 1, 1980, and references therein. 
14. J. A. Porter and A. E. Symonds, Jr., "Precipitation of Plutonium (III) Oxalate and Calcination to Plutonium Dioxide," DP-981, E. I. du Pont de Nemours and Co., Savannah River Laboratory, Aiken, South Carolina, November 1965.

15. J. E. Morrison, private communications, Mechanical Operations, Rocky Flats Plant, Rockwell International, June 8, 1982.

16. E. L. Christensen and W. J. Maramon, "Plutonium Processing at the Los Alamos Scientific
Laboratory," LA-3542, Los Alamos, New Mexico, April 1969, p 56.

17. F. K. Pittman, Chapter 5, "Chemistry Chemistry of the Recovery of Plutonium," in "Chemistry of Uranium and Plutonium," LA-1 100, Los Alamos Scientific Laboratory, 1947.

18. J. M. Cleveland and J. D. Navratil, Rockwell International, Rocky Flats Plant, Golden, Colorado, personal communications, November 4, 1977. 
I L L U S T R A T I O N S

(Figures 1 through 14)

FIGURE 1. Plutonium Peroxide Digest Slurry, Run 2

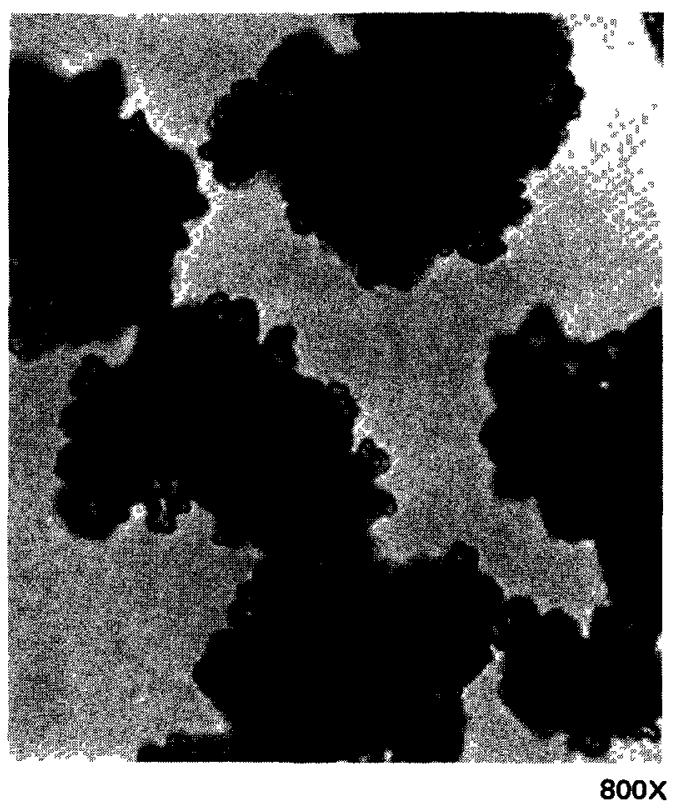

FIGURE 3. Plutonium(III)

Oxalate Slurry, Run 6

$800 x$

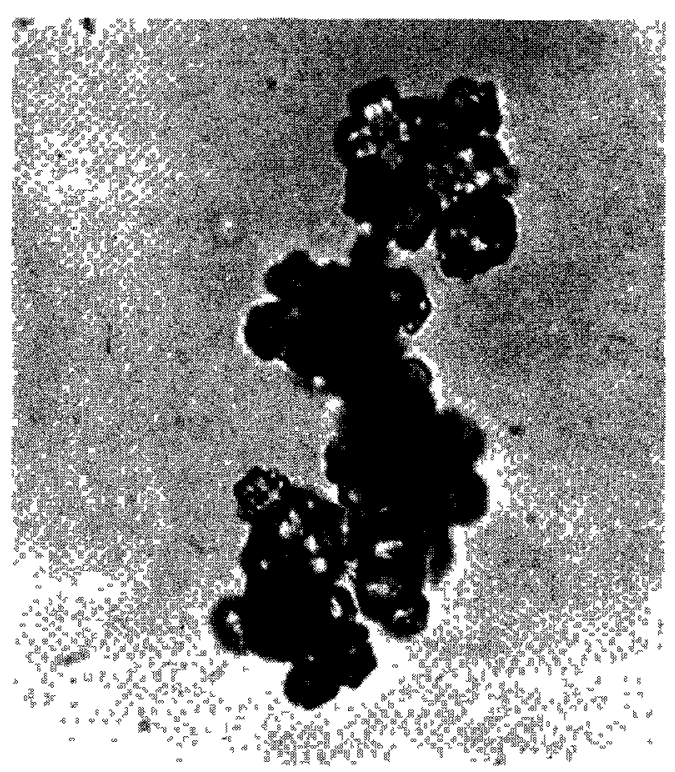

FIGURE 2. Plutonium Tri-

fluoride Digest Slurry, Run 5

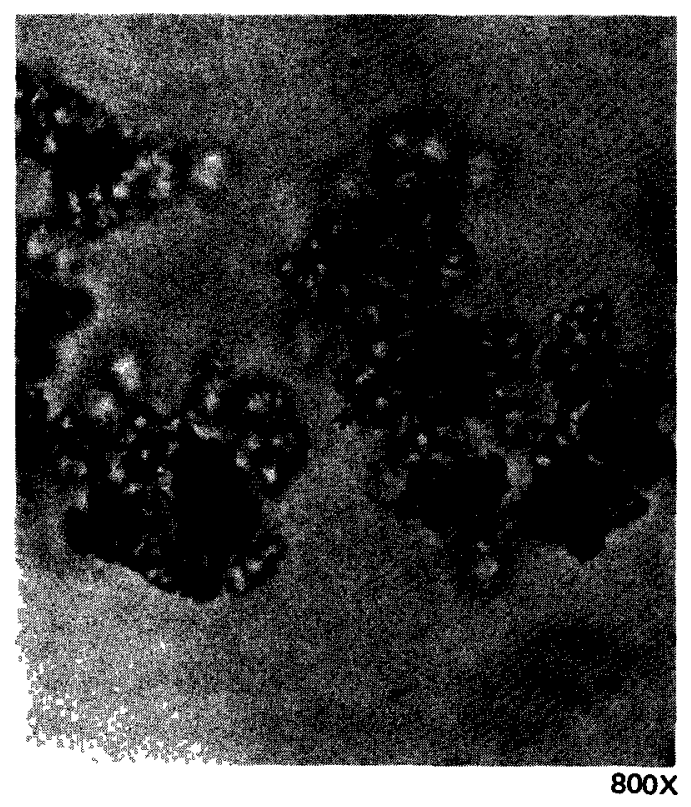

FIGURE 4. Plutonium(III)

Oxalate Slurry, Run 7 800x

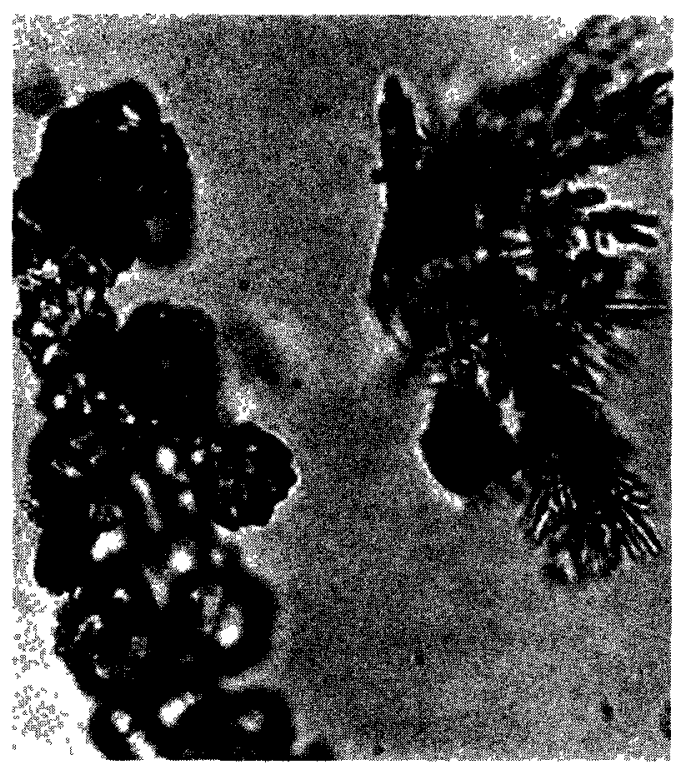




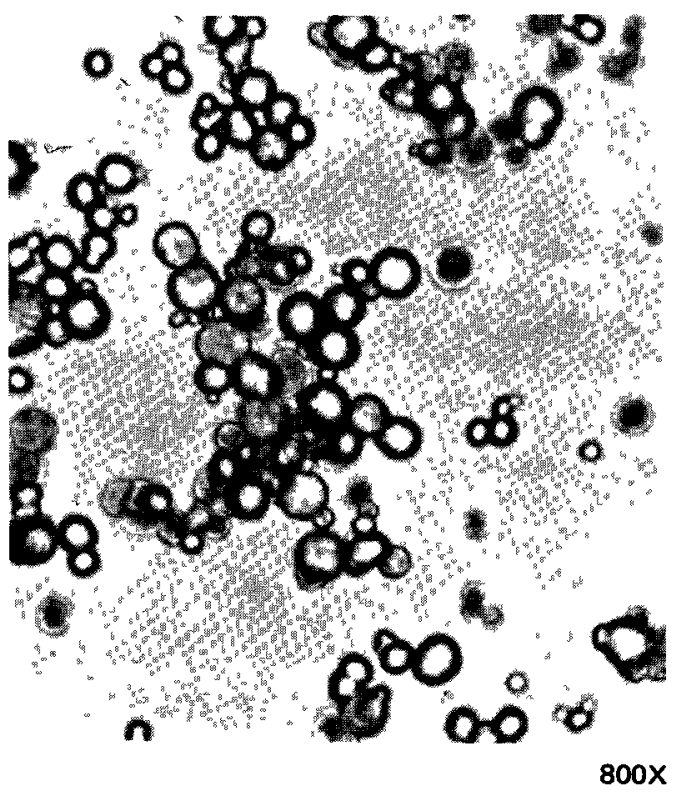

FIGURE 5. Plutonium(IV)

Oxalate Digest Slurry, Run 8

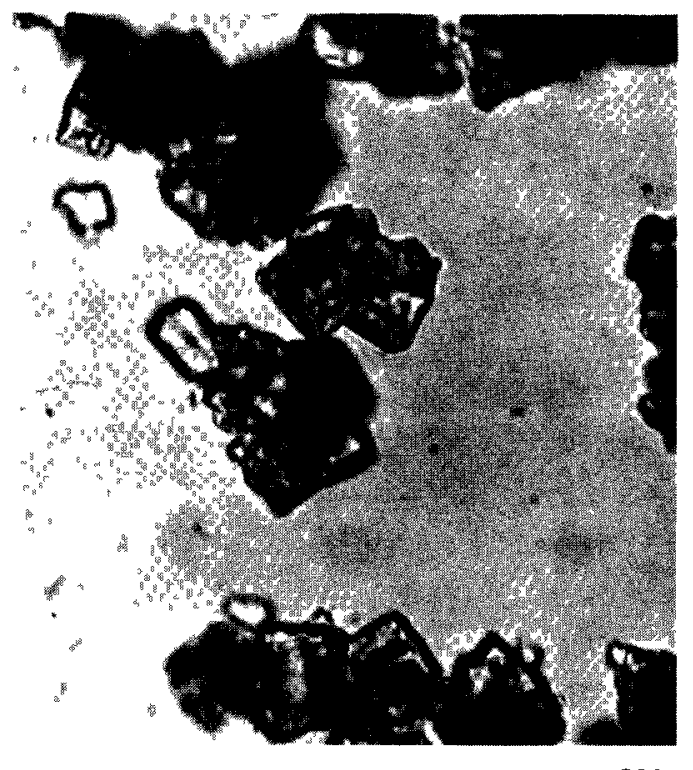

FIGURE 6. Plutonium(IV) Oxa-

late Digest Slurry, Run 11
FIGURE 7. Plutonium(III) Carbonate Digest Slurry, Run 12

$800 x$

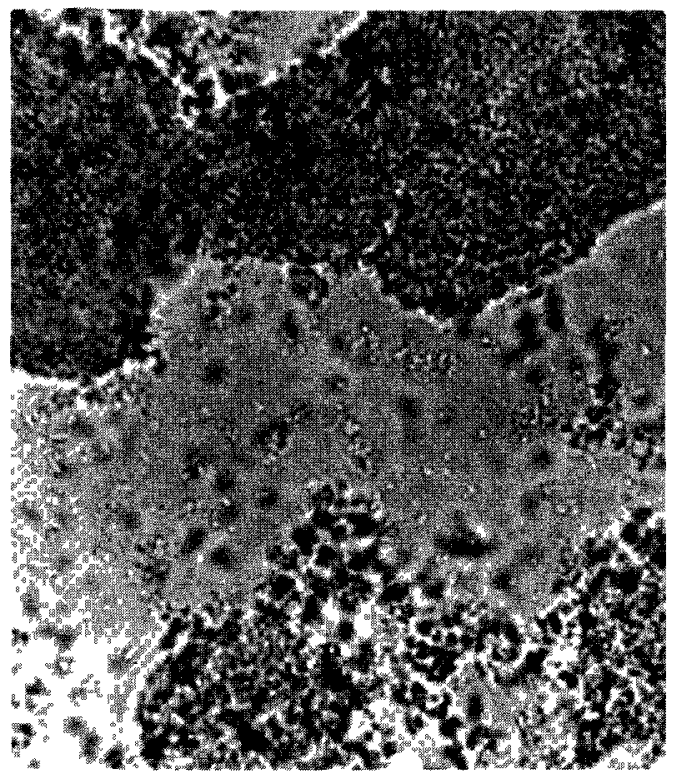

FIGURE 8. Plutonium(IV) Carbonate Digest Slurry, Run 14

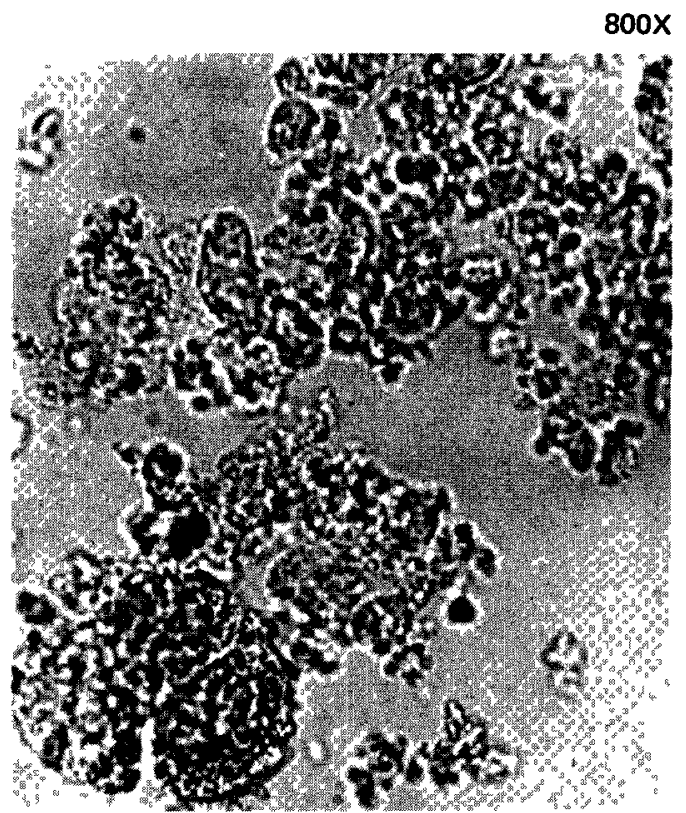




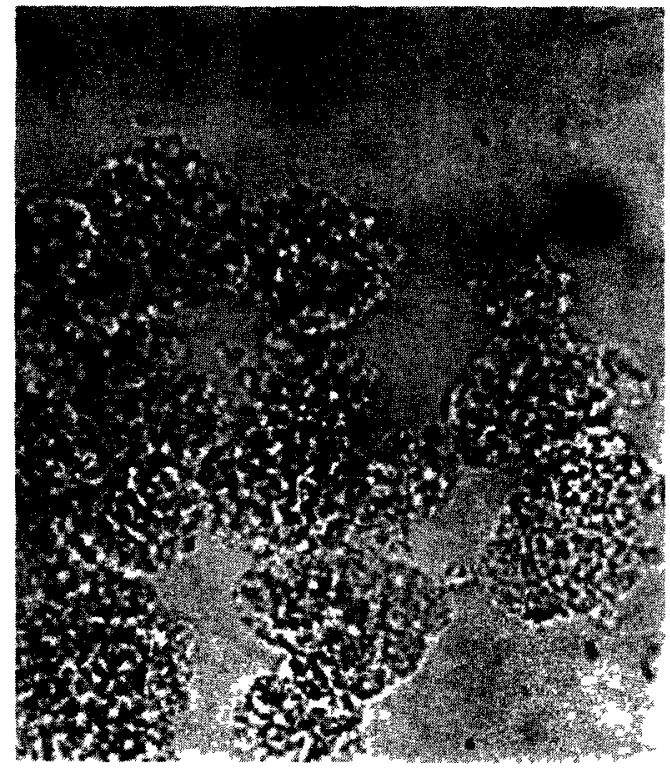

$800 x$

FIGURE $10.40 \%$ Plutonium(IV) - 60\% Plutonium(VI) Carbonate Digest Slurry, Run 17
FIGURE 9. Plutonium(IV) Carbonate Digest Slurry, Run 15

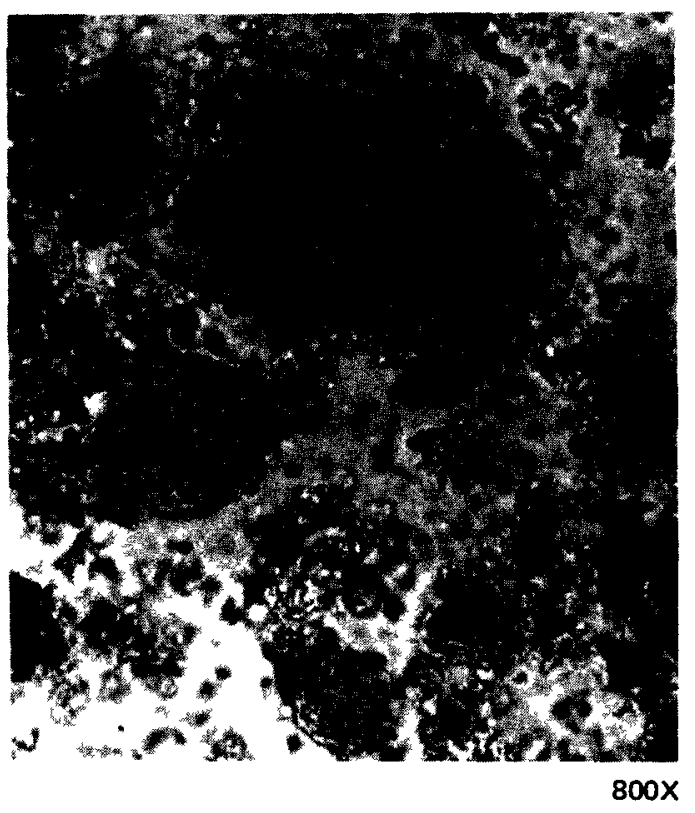

FIGURE 11. Plutonium(VI) Carbonate Digest Slurry, Run 19 


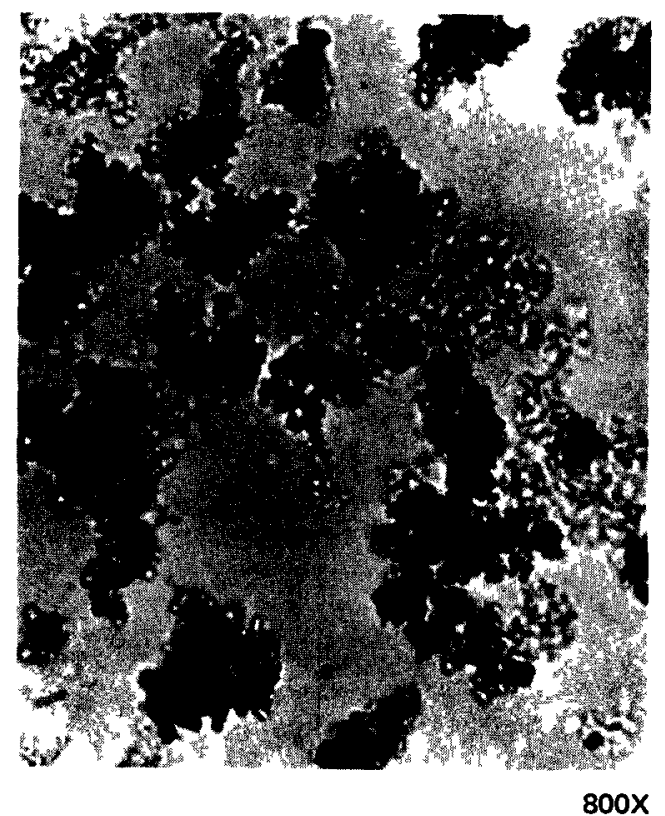

FIGURE 13. Plutonium(IV) Sodium Hydroxide Digest Slurry, Run 22
FIGURE 12. Plutonium(VI) Potassium Hydroxide Slurry, Run 21
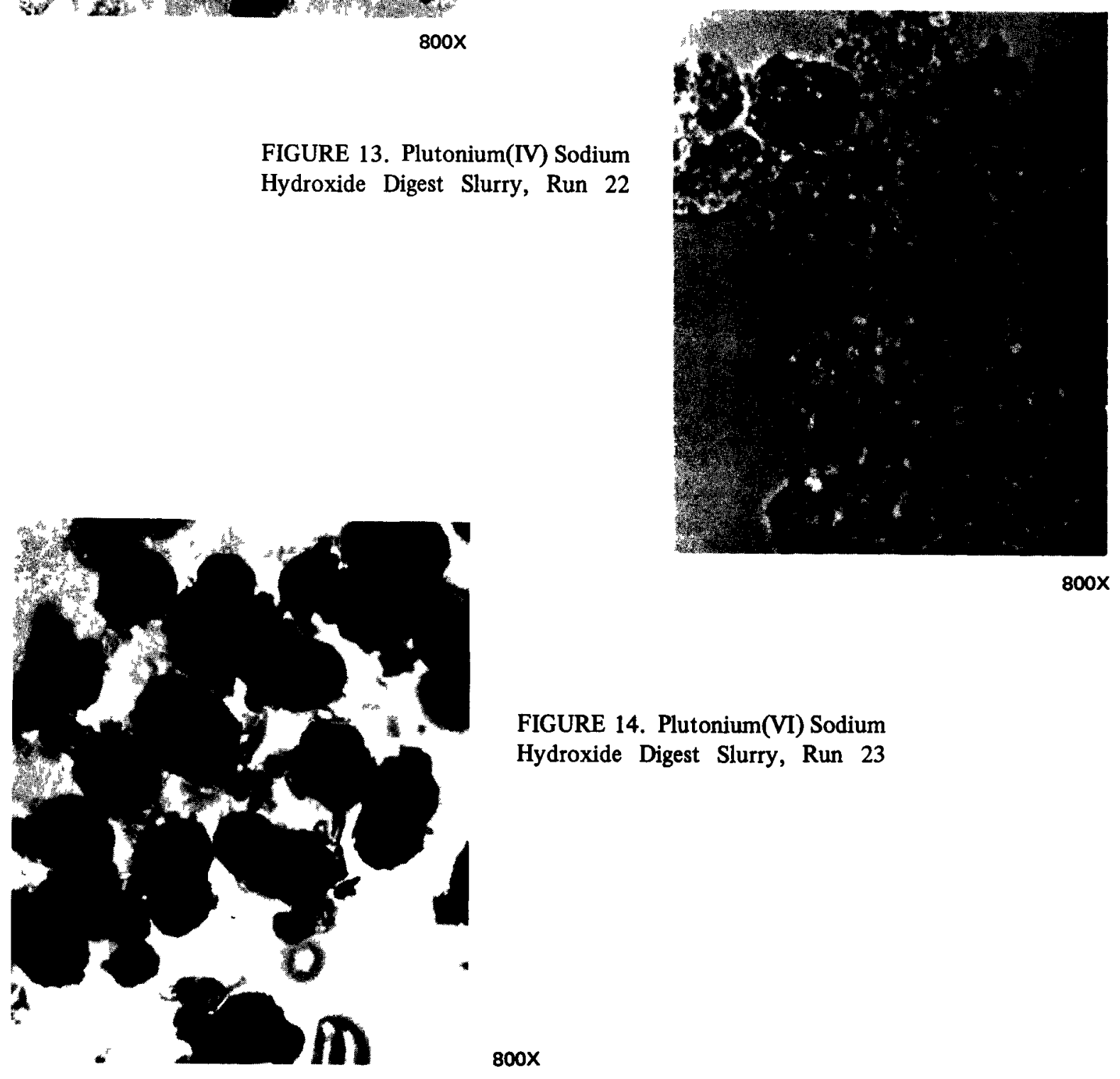

FIGURE 14. Plutonium(VI) Sodium

Hydroxide Digest Slurry, Run 23 